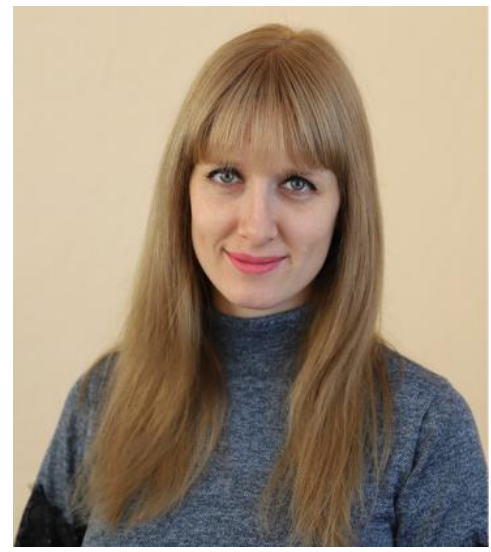

\author{
Марина Нестеренко, \\ старший викладач кафедри початкової освіти \\ Бердянського державного педагогічного університету \\ (м. Бердянськ, Україна)
}

\author{
Marina Nesterenko, \\ Senior Lecturer, \\ Elementary Education Department, \\ Berdiansk State Pedagogical University \\ (Berdiansk, Ukraine) \\ nesterenko_marina1988@ukr.net \\ ORCID ID 0000-0003-3005-5910
}

удк 378.09.011.3-051:373.3.091.32-047.58

\title{
ПЕДАГОГІЧНІ УМОВИ ПІДГОТОВКИ МАЙБУТНІХ УЧИТЕЛІВ ДО МОДЕЛЮВАННЯ УРОКУ В КОНТЕКСТІ ВАРІАТИВНОСТІ ПОЧАТКОВОЇ ОСВІТИ
}

Анотація. У статті визначено та теоретично обґрунтовані педагогічні умови, які забезпечують ефективність профресійної підготовки майбутніх учителів до моделювання уроків в умовах варіативності початкової освіти. Такими в дослідженні виокремлені: організація суб'єкт-суб’єктної взаємодії учасників освітнього процесу, орієнтація викладача на впровадження технології контекстного навчання, активізація рефлексивної позиції майбутніх учителів початкової школи.

Розкрито сутність організації суб'єкт-суб'єктної взаємодії учасників освітнього процесу в ЗВО, що забезпечує перетворення студентів з пасивних споживачів знань на активних їх здобувачів, дослідників, співучасників. Це є особливо цінним для їх підготовки до реалізації Концепції Нової української школи, де пріоритетною визначено педагогіку партнерства.

У роботі проаналізовано ефективність орієнтації викладача на впровадження технології контекстного навчання в формуванні досвіду професійних дій моделювання уроку майбутніх учителів початкової школи, використання активних методів навчання, заснованих на принципах проблемності, а саме лекцій контекстного типу (лекція-діалог контекстного типу, лекція-прес-конференція контекстного типу тощо). інтерактивних методів навчання.

Також розглянуто умову активізації рефлексивної позиції студентів, що забезпечує оволодіння ними навичками конструктивного аналізу якості реалізації власних педагогічних задумів і спрямовує на постійне самовдосконалення.

Ключові слова: професійна підготовка майбутніх учителів початкової школи, педагогічні умови, мотивація, контекстне навчання, рефлексія.

\section{PEDAGOGICAL CONDITIONS OF THE PREPARATION OF FUTURE TEACHERS FOR MODELING THE LESSON IN THE CONTEXT OF VARIATIVITY OF THE PRIMARY EDUCATION}

Abstract. The pedagogical conditions that ensure the effectiveness of the professional training of future teachers for modeling lessons in the context of variativity of the primary education are identified and theoretically substantiated in the article.

The relevance of the designated topic is determined by the need for new pedagogical personnel capable of operating effectively in the context of reforming the primary education system based on the Concept of the New Ukrainian School, using the resource of its variativity when modeling lessons.

Thus, by the method of analysis and generalization of the data of psychological and pedagogical scientific literature on the problem, in our study, the following conditions for preparing future teachers for modeling a lesson in the context of the variativity of primary education are highlighted: the organization of the subject-subjective interaction of participants in the educational process, the orientation of the teacher to the introduction of contextual learning technology, enhancing the reflexive position of future teachers of primary school.

The essence of the organization of the subject-subjective interaction of the participants of the educational process in the higher educational establishments is revealed, which ensures the transformation of students from passive knowledge consumers into their active seekers, researchers, accomplices. This is especially valuable for their preparation for the implementation of the New Ukrainian School Concept, where partnership pedagogy is defined as a priority.

The paper analyzes the effectiveness of the orientation of the teacher on the introduction of contextual learning technology in the formation of the experience of professional activities of modeling the lesson of future primary school teachers.

Also the condition for the activation of the students' reflexive position is considered, which ensures that they master the skills of a constructive analysis of the quality of the implementation of the own pedagogical plans and directs them to continuous selfimprovement.

The combination of the named conditions for the organization of the educational process in a higher educational establishment allows overcoming the inertia of thinking of future primary school teachers, contributes to their ability to simulate lessons (classes) in the context of the variativity of primary education, motivates them to productive pedagogical activities, promotes the development of skills for continuous self-development.

Keywords: vocational training of future primary school teachers, pedagogical conditions, motivation, contextual learning, reflection. 


\section{ВСТУП}

Постановка проблеми. Модернізація освіти спрямована на підготовку особистості молодшого школяра до успішної самореалізації в суспільстві. Особлива увага надається розвитку ключових і предметних компетентностей, необхідних життєвих і соціальних навичок. Щоб відповідати викликам часу, початкова школа має швидко реагувати на інноваційні зміни, де пріоритетним є впровадження ідей педагогіки партнерства, суть якої полягає подоланні інертності мислення педагога, його вміннях організувати суб'єкт-суб'єктну взаємодію між учасниками освітнього процесу. Концепція Нової української школи відображає нові вимоги до вчителя, здатного плекати українську ідентичність; готувати авторські навчальні програми; створювати навчально-предметне середовище, засноване на цінностях дитинства; налагоджувати постійний діалог з батьківською спільнотою, громадськістю тощо. Традиційна система підготовки майбутніх педагогів у закладах вищої освіти недостатньо спрямована на забезпечення таких змін.

Аналіз останніх досліджень і публікацій. Проблема професійної підготовки майбутніх учителів до моделювання уроків в умовах варіативності початкової освіти у вітчизняній науковій літературі подається різноаспеткно: характеристика загальнодидактичного складника змісту освітнього процесу (В. Бондар, О. Савченко, П. Гусак, О.Бігіч, Н. Воскресенська, О. Коханко, Н. Максименко І. Колеснікова, І. Шапошнікова та ін.); висвітлення методичних і технологічних засад моделювання уроку (Н. Бібік, О. Біда, М. Богданович, М. Вашуленко, Л. Коваль, А. Коломієць, О. Комар, Л. Кочина, О. Онопрієнко, Л. Петухова, О. Савченко, С. Скворцова та ін.).

META I ЗАВДАННЯ ДОсЛІДЖЕННЯ - розкрити педагогічні умови організації освітнього процесу в закладах вищої освіти, які спрямовуються на реалізацію Концепції Нової української школи, а саме підготовку майбутнього вчителя до моделювання сучасного уроку в початковій школі.

МЕТОДИ ДОСЛІДЖЕННЯ: аналіз і узагальнення психолого-педагогічної наукової літератури з проблеми.

\section{РЕЗУЛЬТАТИ ДОСЛІДЖЕННЯ}

Виокремимо педагогічні умови організації освітнього процесу в закладах вищої освіти, які спрямовуються на реалізацію Концепцію Нової української школи, зокрема підготовку майбутнього вчителя до моделювання сучасного уроку в початковій школі, тобто формування їх моделювальної компетентності:

1) Організація суб'єкт-суб'єктної взаємодії учасників освітнього процесу.

2) Орієнтація викладача на впровадження технології контекстного навчання.

3) Активізація рефлексивної позиції майбутніх учителів початкової школи.

Схарактеризуємо суть кожної з означених педагогічних умов.

Проблема суб'єкт-суб'єктної взаємодії в освітньому процесі набула актуальності на хвилі розвитку гуманістичної концепції та знайшла своє відображення в наукових працях І. Андрощук, Л. Велитченка, І. Глазкової, В. Гриньової, В. Кручек, О. Легун, О. Ліннік, О. Пінської, О. Савченко та ін.

Сутність суб'єкт-суб'єктної взаємодії, на думку О. Ліннік, полягає в рівноправному взаємообміні між суб'єктами освітнього процесу, що відбувається в спільній навчальній діяльності та опосередковується особистісними стосунками. Це найвищий рівень педагогічної взаємодії, який характеризується співробітництвом та співпрацею в закладах вищої освіти. Сучасне студентоцентроване середовище якраз потребує суб'єкт-суб'єктного типу взаємодії, яка ґрунтується на принципах діалогічного спілкування. Ядром навчального діалогу є рівноправність позицій: повага викладача до думок і вчинків студента, вміння бачити в ньому активного учасника освітнього процесу та реалізовувати цю роль. За таких умов можлива продуктивна пізнавальна діяльність: пошук, постановка та розв'язання творчих завдань, спільне дослідження, результатом чого є особистісно цінні знання та способи дій [5, с 203].

Серед чинників, які впливають на забезпечення суб'єкт-суб'єктної педагогічної взаємодії, І. Андрощук виокремлює: організаційно-педагогічні (загальна спрямованість освітнього процесу на творчу співпрацю); особистісні (культура, організаторські здібності та якості викладачів); професійні (цінності педагогів, рівень їхньої педагогічної майстерності та компетентності); соціально-економічні (заробітна плата, умови діяльності) тощо [1, с 47].

Важливим психологічним чинником суб'єкт-суб'єктної педагогічної взаємодії в закладі вищої освіти, як зазначає О. Пінська, є загальні відносини між учасниками освітнього процесу, які ніколи не бувають нейтральними: вони або сприяють її організації, або заважають, залежно від того, є вони відносинами співпраці та співтворчості чи домінування й авторитаризму. Тому організація студентоцентрованого освітнього середовища передбачає залучення студентів до обговорення та спільного виконання дій, прийняття рішень; урахування специфіки академічної групи, її установок, прагнень, інтересів, ціннісних орієнтацій [6].

Отже, суб'єкт-суб'єктна взаємодія всіх учасників освітнього процесу створює умови для організації студентоцентрованого середовища, де кожен сприймається як повноцінна особистість, що забезпечує взаємозбагачення, саморозвиток, здатність до інноваційної діяльності як викладача, так і майбутнього фахівця.

Другою педагогічною умовою є орієнтація викладача на впровадження технології контекстного навчання, яка позитивно впливає на формування моделювальної компетентності майбутніх учителів початкової школи.

Особливості технології контекстного навчання висвітлюються в наукових доробках А. Вербицького, Н. Дем'яненко, В. Желанової, В. Іщук, Л. Коваль, І. Марчук, Т. Ніконенко та ін. Смислоутворювальним поняттям зазначеної технології $€$ контекст, який Л. Коваль пояснює як систему внутрішніх і зовнішніх умов та чинників поведінки й діяльності людини, що впливають на сприйняття, розуміння й перетворення суб'єктом конкретної ситуації. Сутність технології контекстного навчання, як переконує науковець, полягає в створенні професійного контексту майбутньої діяльності шляхом моделювання цілісних фрагментів [4].

На думку Н. Дем'яненко, упровадження в процес підготовки фрахівців педагогічного профрілю професійного контексту передбачає організацію діяльності студентів через розв'язання ними системи практико-орієнтованих завдань [2, с. 13]. 
Особливу цінність технології контекстного навчання В. Желанова вбачає під час організації на практичних заняттях ділових ігор, де студенти здійснюють аналіз педагогічних ситуацій та розв'язують квазіпрофресійні завдання, і виробничої практики, що забезпечує перехід від контекстного навчання до реалій професії вчителя початкової школи [3].

Сучасна педагогічна діяльність з моделювання уроку в умовах варіативності початкової освіти вимагає компетентного та нестандартного розв'язання низки завдань, що $є$ неможливим лише за наявності знань і вмінь створювати типовий урок за універсальним алгоритмом. Це $є$ сферою прояву творчих можливостей учителя та гнучкості його професійного педагогічного мислення.

Експрес-аналіз феномену педагогічного мислення (О. Акімова, В. Бондар, Л. Джелілова, Т. Дяк, А. Зубрик, К. Костюченко, Н. Малій, О. Митник, Г. Нагорна, С. Карпенчук, Ю. Кулюткін, Г. Сухобська, Л. Ткаченко та ін.) засвідчує, що він відображає рівень розвитку розумових, пізнавальних, творчих і пошуково-дослідницьких здібностей майбутнього вчителя початкової школи, його операційно-технологічних умінь, які полягають у знаходженні шляхів розв'язання будь-якої проблемної ситуації.

Конкретизуючи, вважаємо, що педагогічне мислення вчителя початкової школи характеризується оперативністю (швидке прийняття оптимальних методичних рішень із арсеналу знайомих або їх пошук), гнучкості (відходження від звичних стереотипів професійної діяльності), креативності (творче експериментування, новаторство), прогностичності (урахування можливостей моделювання сучасного уроку та передбачуваних результатів).

На формування педагогічного мислення майбутніх учителів початкової школи позитивний вплив мають лекції контекстного типу, створення педагогічних ситуацій, які розв'язуються студентами за допомогою квазіпрофесійних завдань, тощо.

Аналіз наукових праць (Н. Дяченко, Н. Кузьміна, М. Кашапов, М. Левина, Л. Мільто, О. Пєхота, О. Самойленко, А. Старєва та ін.) дозволяє узагальнити визначення педагогічної ситуації як:

- сукупність умов, засобів спілкування, мотивів і цілей суб'єктів педагогічної діяльності відповідно до предметного змісту;

- проектування образу й створення контексту майбутньої професійної діяльності.

Аналіз психолого-педагогічних досліджень (В. Безпалько, І. Лернер, М. Скаткін та ін.) переконливо доводить, що створення в освітньому процесі середовища контекстного типу (за допомогою педагогічних ситуацій) дозволяє ефективно впливати на формування моделювальної компетентності майбутніх педагогів. Педагогічні ситуації поділяються на репродуктивні, репродуктивно-творчі та проблемні.

Для нашого дослідження важливо спинитися на характеристиці проблемних ситуацій (А. Вербицький, Н. Гавриш, М. Кашапов, Л. Коваль, Л. Мільто Л. Пєтухова, С. Скворцова та ін.), оскільки застосування їх в освітньому процесі забезпечує розвиток педагогічного мислення майбутніх учителів початкової школи, що дозволяє співвідносити розумові й практичні дії педагога зі змістом, умовами реалізації; здійснювати рефлексивну діяльність. У проблемній ситуації студент не має готового зразка, алгоритму, правила її розв'язання, а відшукує їх самостійно.

У процесі експериментального навчання нами спеціально моделювались педагогічні ситуації, які розв'язувалися за допомогою системи квазіпрофесійних завдань, представлених трьома групами: дидактичні, методичні та технологічні.

Дидактичні квазіпрофресійні завдання пропонувалися студентам 3 метою усвідомлення педагогічного моделювання як особистісно значущого процесу для професійної діяльності та фрормування основ цілісного його бачення («Дидактика»).

Методичні квазіпрофесійні завдання впроваджувалися для формування в майбутніх педагогів умінь планувати, здійснювати вибір ресурсного забезпечення та конструювати моделі уроків в умовах варіативності початкової освіти.

Технологічні квазіпрофесійні завдання спрямовувалися на формування в студентів здатності проводити й аналізувати урок (систему уроків) на основі впровадження сучасних навчальних технологій в умовах варіативності; здійснювати контрольно-оцінювальну діяльність на уроці; готовності до саморозвитку та самовдосконалення.

Отже, орієнтація викладача на впровадження технології контекстного навчання, по-перше, забезпечує практикоорієнтований характер підготовки майбутніх учителів початкової школи на основі аналізу педагогічних ситуацій та виконання квазіпрофесійних завдань; по-друге, суттєво впливає на розвиток їх педагогічного мислення, що дозволяє перетворювати обмежений досвід моделювання уроків в умовах варіативності початкової освіти в універсальну здатність до цієї діяльності.

Третя педагогічна умова - активізація рефлексивної позиції майбутніх учителів початкової школи.

Питання рефлексивної діяльності, знаходячись на перетині педагогічної та психологічної науки, привертало увагу багатьох дослідників у таких аспектах: рефлексивних умінь студентів педагогічних фракультетів (С. Білоконний, О. Герасимова, А. Лозенко); формування профресійної рефлексії (рефлексивної позиції) майбутніх учителів початкової школи (М. Марусинець); рефлексивної культури педагога (Г. Дегтяр, К. Павелків); рефлексивної компетентності (О. Кравців, О. Савченко, І. Ульяніч) тощо.

Підвищення інтересу до розвитку рефлексивних умінь майбутніх учителів початкової школи, як правило, пов'язують з активним упровадженням в освітній процес особистісно зорієнтованого підходу - умови фрормування індивідуальної стратегії професійного вдосконалення, що потребує готовності студентів до розв'язання творчих завдань.

Крім того, модернізація освітнього простору початкової школи вимагає від учителя постійного самовдосконалення, саморозвитку і самооцінки власних досягнень - становлення рефлексивної позиції. Вона, на думку М. Марусинець, є інтегральним особистісним утворенням, що визначається сукупністю здібностей, способів та стратегій, які забезпечують подолання професійних проблем за допомогою мисленнєвих операцій (усвідомлення, аналіз, переосмислення), і виступає механізмом пошуку шляхів особистісного зростання [7]. 
Рефлексивну позицію особистості з психологічної точки зору (О. Кравців, О. Савченко, І. Ульяніч) пояснюють як поєднання декількох компонентів: інформаційного (усвідомлення суб'єктом власної рефлексивної активності), інструментального (рефлексивні вміння), оцінно-мотиваційного (здібності суб'єкта до прогнозування подій власної життєдіяльності), поведінкового (когнітивно-стильові властивості рефлексивної діяльності) тощо. Ці елементи здійснюють мобілізацію операційних та поведінкових ресурсів особистості й забезпечують організацію відповідних дій і контроль за виявом рефлексивної позиції особистості [8].

Таким чином, активізація рефлексивної позиції майбутніх учителів початкової школи, яка забезпечує цілісне уявлення про зміст, способи та засоби своєї діяльності, робить людину суб'єктом власної активності, а отже,

$€$ стійкою внутрішньою системою установок особистості студента на здійснення професійної рефлексивної діяльності, яка проявляється в його здатності критично аналізувати допущені помилки під час моделювання сучасного уроку з їх наступною корекцією, визначати подальші перспективи педагогічного задуму тощо.

У нашому дослідженні реалізація педагогічних умов підготовки майбутніх учителів до моделювання уроків у контексті варіативності початкової освіти забезпечувалася за рахунок упровадження в освітній процес активних методів навчання, заснованих на принципах проблемності, а саме лекцій контекстного типу (лекція-діалог контекстного типу, лекція-прес-конференція контекстного типу тощо).

Не менш важливим для фрормування моделювальної компетентності майбутніх учителів під час практичних і лабораторних занять було використання інтерактивних методів навчання, зокрема мозковий штурм (мозкова атака), дискусія, дебати, різні види тренінгів тощо.

\section{ВИСНОВКИ ТА ПЕРСПЕКТИВИ ПОДАЛЬШИХ ДОСЛІДЖЕНЬ}

Обґрунтовані вище педагогічні умови підготовки майбутніх учителів до моделювання уроків, ураховуючи пріоритетність варіативності початкової освіти (організація суб'єкт-суб'єктної взаємодії учасників освітнього процесу; орієнтація викладача на впровадження технології контекстного навчання; активізація рефлексивної позиції майбутніх учителів початкової школи), дозволяють підвищити ефективність формування їх моделювальної компетентності.

\section{СПИСОК ВИКОРИСТАНИХ ДЖЕРЕЛ}

[1] Андрощук І. В. Педагогічна взаємодія у професійній діяльності: навч. посіб. Хмельницький: ХНУ, 2017. 190 с.

[2] Дем'яненко Н. М. Контекстно-професійна підготовка майбутнього викладача вищого навчального закладу. Оптимізація ци-клу соціально-гуманітарних дисциплін у вищій освіті України в контексті євроінтеграції: монографрія. Київ, 2014. С. 88-119

[3] Желанова В. В. Контекстне навчання майбутнього вчителя початкових класів: теорія і технологія: монографія. Луганськ, 2013. $482 \mathrm{c}$.

[4] Коваль Л. В. Професійна підготовка майбутніх учителів у контексті розвитку початкової освіти: монографія. 2-ге вид., перероб. і допов. Донецьк: ЛАНДОН-XXI, 2012. 343 с.

[5] Ліннік О. О. Майбутній учитель як суб'єкт педагогічної взаємодії: підготовка до співробітництва з молодшими школярами: монографія. Київ: Слово, 2014. 302 с.

[6] Пінська О. Л., Шепеленко О. Л. Теоретичні засади організації педагогічної взаємодії в навчальному процесі вищих закла-дів освіти. Педагогіка вищої та середньої школи. 2014. Вип. 40. С. 308-313.

[7] Марусинець М. М. Система формування професійної рефлексії майбутніх учителів початкових класів: дис. ... д-ра пед. наук: 13.00.04. Івано-Франківськ, 2012. 454 с.

[8] Савченко О. В. Психологія рефлексивної компетентності особистості: автореф. дис. ... д-ра психол. наук: 19.00.01. Київ, 2017. 38 c.

\section{REFERENCES (TRANSLATED AND TRANSLITERATED)}

[1] Androshhuk I.V. Pedaghoghichna vzajemodija u profesijnij dijaljnosti (Pedagogical interaction in professional activity): navch. posib. Khmeljnycjkyj: KhNU, 2017. 190 s. (in Ukrainian)

[2] Dem'janenko N.M. Kontekstno-profesijna pidghotovka majbutnjogho vykladacha vyshhogho navchaljnogho zakladu. Optymizacija cyklu socialjno-ghumanitarnykh dyscyplin u vyshhij osviti Ukrajiny v konteksti jevrointeghraciji (Context-professional training of a future teacher of higher education. Optimization of the cycle of social and humanitarian disciplines in higher education of Ukraine in the context of European integration): monoghrafija. Kyjiv, 2014. S. 88-119. (in Ukrainian)

[3] Zhelanova V.V. Kontekstne navchannja majbutnjogho vchytelja pochatkovykh klasiv: teorija i tekhnologhija (Contextual education for the future teacher of elementary school: theory and technology): monoghrafija. Lughansjk, 2013. $482 \mathrm{~s}$. (in Ukrainian)

[4] Kovalj L.V. Profesijna pidghotovka majbutnikh uchyteliv u konteksti rozvytku pochatkovoji osvity (Professional training of future teachers in the context of the development of primary education): monoghrafija. 2-ghe vyd., pererob. i dopov. Donecjk: LANDON-KhKhl, 2012. $343 \mathrm{~s}$. (in Ukrainian)

[5] Linnik O.O. Majbutnij uchytelj jak sub'jekt pedaghoghichnoji vzajemodiji: pidghotovka do spivrobitnyctva z molodshymy shkoljaramy (Future teacher as a subject of pedagogical interaction: preparation for cooperation with junior schoolchildren): monoghrafija. Kyjiv: Slovo, 2014. 302 s. (in Ukrainian)

[6] Pinsjka O.L., Shepelenko O.L. Teoretychni zasady orghanizaciji pedaghoghichnoji vzajemodiji $v$ navchaljnomu procesi vyshhykh zakladiv osvity (Theoretical foundations of organization of pedagogical interaction in the educational process of higher educational institutions). Pedaghoghika vyshhoji ta serednjoji shkoly. 2014. Vyp. 40. S. 308-313. (in Ukrainian)

[7] Marusynecj M.M. Systema formuvannja profesijnoji refleksiji majbutnikh uchyteliv pochatkovykh klasiv (The system of formation of professional reflection of future teachers of elementary school): dys. ... d-ra ped. nauk: 13.00.04. Ivano-Frankivsjk, $2012.454 \mathrm{~s}$. (in Ukrainian)

[8] Savchenko O.V. Psykhologhija refleksyvnoji kompetentnosti osobystosti (Psychology of the reflective competence of the individual): avtoref. dys. ... d-ra psykhol. nauk: 19.00.01. Kyjiv, 2017. 38 s. (in Ukrainian) 